\title{
ON A COLLECTION OF CRINOIDS OF THE GENUS EUDIO- CRINUS FROM JAPAN, WITH DESCRIPTION OF A NEW SPECIES.
}

\author{
By Austin H. Clark, \\ Of the United States Burean of Fisheries.
}

The collections brought back by the United States Fisheries steamer Albatross from Japan contained, among many other interesting forms, 320 comatulids belonging to the genus Eudiocrimus, which, with three others in the United States National Museum, also obtained in Japan, form the basis of the present paper.

Eudiocrinus was found in abundance along the entire southern shore of Japan, from southern Kiusiu and the Linschoten Islands to the Gulf of Tokio, in water varying from 103 to 712 fathoms, with a bottom temperature of from $37.5^{\circ}$ to $56.0^{\circ} \mathrm{F}$. Only two species are represented in the 1906 collection, but the specimens in the National Museum taken in 1896 prove to belong to a third species which we did not meet with.

EUDIOCRINUS VARIANS P. H. Carpenter.

There were collected 238 specimens from the following localities:

Station No. 4906. - $31^{\circ} 39^{\prime} 00^{\prime \prime}$ north latitude, $129^{\circ} 20^{\prime} 30^{\prime \prime}$ east longitude, Tsurikake Saki Light bearing south $85^{\circ}$ east, 17.2 miles distant. Depth, 369 to 406 fathoms; bottom temperature, $43.4^{\circ} \mathrm{F}$.; no bottom specimen. August 11, 1906.

One small specimen.

Station No. 4911. - $31^{\circ} 38^{\prime} 30^{\prime \prime}$ north latitude, $129^{\circ} 19^{\prime} 00^{\prime \prime}$ east longitude, Tsurikake Saki Light bearing south $88^{\circ}$ east, 18 miles distant. Depth, 391 fathoms; bottom temperature, $41.9^{\circ} \mathrm{F}$.; bottom, gray globigerina ooze. August 12, 1906.

Four rather small specimens.

Station No. 4912. - $31^{\circ} 39^{\prime} 40^{\prime \prime}$ north latitude, $129^{\circ} 20^{\prime} 00^{\prime \prime}$ east longitude, Tsurikake Saki Light bearing south $84^{\circ}$ east 17.5 miles distant. Depth, 391 fathoms; bottom temperature, $41.9^{\circ} \mathrm{F}$.; bottom, gray globigerina ooze. August 12, 1906.

Thirteen medium-sized specimens. 
Station No. 4915. - $31^{\circ} 31^{\prime} 00^{\prime \prime}$ north latitude, $129^{\circ} 25^{\prime} 30^{\prime \prime}$ east longitude, Tsurikake Saki Light bearing north $62^{\circ}$ east, 14.8 miles distant. Depth, 427 fathoms; bottom temperature, $41.9^{\circ} \mathrm{F}$.; bottom, gray globigerina ooźe and broken shell. August 12, 1906.

One small specimen.

Station No. 4916. - $30^{\circ} 25^{\prime} 00^{\prime \prime}$ north latitude, $129^{\circ} 06^{\prime} 40^{\prime \prime}$ east longitude, Gwaja Shima bearing south $37^{\circ}$ east, 37.5 miles distant. Depth, 361 fathoms; bottom temperature, $42.7^{\circ} \mathrm{F}$; bottom, gray sand, globerina ooze, and broken shell. August 13, 1906.

Three medium-sized specimens.

Station No. 4919. - $30^{\circ} 34^{\prime} 00^{\prime \prime}$ north latitude, $129^{\circ} 22^{\prime} 00^{\prime \prime}$. east longitude, Kusakaki Jima bearing north $10^{\circ}$ east, 17.5 miles distant. Depth, 440 fathoms; bottom temperature, $41.8^{\circ} \mathrm{F}$; ; bottom, globigerina ooze. August 13, 1906.

One hundred and four medium-sized specimens.

Station No. 4920. - $30^{\circ} 34^{\prime} 00^{\prime \prime}$ north latitude, $129^{\circ} 22^{\prime} 00^{\prime \prime}$ east longitude, Kusakaki Jima bearing north $10^{\circ}$ east, 17.5 miles distant. Depth, 440 fathoms; bottom temperature, $41.8^{\circ} \mathrm{F}$; bottom, globigerina ooze. August 13, 1906.

Five specimens.

Station No. 4975. - $33^{\circ} 21^{\prime} 30^{\prime \prime}$ north latitude, $135^{\circ} 38^{\prime} 50^{\prime \prime}$ east longitude, Shio Misaki Light bearing north $49^{\circ}$ east, 7 miles distant. Depth, 712 fathoms; bottom temperature, $37.5^{\circ} \mathrm{F}$; bottom, brown mud, pebbles, and foraminifera. August 31, 1906.

Nine medium-sized specimens.

Station No. 508\%. - $34^{\circ} 05^{\prime} 00^{\prime \prime}$ north latitude, $137^{\circ} 59^{\prime} 00^{\prime \prime}$ east lon gitude, Omai Saki Light bearing north $22^{\circ}$ east, 33 miles distant. Depth, 662 fathoms; bottom temperature, $37.7^{\circ} \mathrm{F}$; bottom, green mud, fine sand, globigerina ooze. October 20, 1906.

Seventy medium-sized specimens.

Station No. 5083. - $34^{\circ} 04^{\prime} 20^{\prime \prime}$ north latitude, $137^{\circ} 57^{\prime} 30^{\prime \prime}$ east longitude, Omai Saki Light bearing north $23 \frac{1}{2}^{\circ}$ east, 34.5 miles distant. Depth, 624 fathoms; bottom temperature, $38.1^{\circ} \mathrm{F}$.; bottom, fine gray sand and globigerina ooze. October 20, 1906.

Twenty-eight large specimens.

This species was obtained at depths varying from 361 to 712 fathoms and at temperatures of from $37.5^{\circ}$ to $43.4^{\circ} \mathrm{F}$., the average depth being 483.6 fathoms and the mean temperature being $40.8^{\circ} \mathrm{F}$. The specimens from Station No. 5083 were the largest, measuring: arms, 106 $\mathrm{mm}$; longest cirri, $50 \mathrm{~mm}$. There is considerable variation in this species in regard to the extent of the first brachials beyond the centrodorsal. In most of the examples the first brachials are fairly conspicuous, but in one or two they do not show at all, so that the first pinnule is borne on the lowest visible arm joint. The arms and cirri are long 
and slender, the centro-dorsal comparatively small, giving this species a remarkably attenuated appearance. The color in life is a dull purplish brown, the skeleton and cirri nearly white, the disc black.

\section{EUDIOCRINUS JAPONICUS P. H. Carpenter.}

There were collected 82 specimens from the following localities:

Station No. 4900.-32 $28^{\prime} 50^{\prime \prime}$ north latitude, $128^{\circ} 34^{\prime} 40^{\prime \prime}$ east longitude, Ose Saki Light bearing north $83^{\circ}$ east, 14.5 miles distant. Depth, 207 fathoms; bottom temperature, $52.9^{\circ} \mathrm{F}$.; bottom, fine gray sand and broken shell. August 10, 1906.

Four small specimens.

Station No. 4903. - $32^{\circ} 31^{\prime} 10^{\prime \prime}$ north latitude, $128^{\circ} 33^{\prime} 20^{\prime \prime}$ east longitude, Ose Saki Light bearing north $22^{\circ}$ east, 6 miles distant. Depth, 139 to 107 fathoms; bottom temperature, $52.9^{\circ} \mathrm{F}$; bottom, gray sand and broken shell. August 10, 1906.

Two medium-sized specimens.

Station No. 4916. - One medium-sized specimen.

Station No. 4919. - Two specimens.

Station No. 4934.- $30^{\circ} 58^{\prime} 30^{\prime \prime}$ north latitude, $130^{\circ} 32^{\prime} 00^{\prime \prime}$ east longitude, Sata Misaki Light bearing north $77 \frac{1}{2}$ east, 7 miles distant. Depth, 152 to 103 fathoms; bottom temperature, $56.0^{\circ} \mathrm{F}$.; bottom, rocky. August 16, 1906.

Thirteen medium-sized specimens.

Station No. 4958. - $32^{\circ} 36^{\prime} 20^{\prime \prime}$ north latitude, $132^{\circ} 24^{\prime} 30^{\prime \prime}$ east longitude, Mizimoko Shima Light bearing north $26^{\circ}$ west, 29.3 miles distant. Depth, 405 fathoms; bottom temperature, $40.1^{\circ} \mathrm{F}$; bottom, green and brown mud, fine gray sand, and foraminifera. August 23, 1906.

Eleven large specimens.

Station No. 49\%5.-Two medium-sized specimens.

Station No. 49\%6. - $33^{\circ} 22^{\prime} 50^{\prime \prime}$ north latitude, $135^{\circ} 38^{\prime} 30^{\prime \prime}$ east longitude, Shio Misaki Light bearing north $59^{\circ}$ east, 6.4 miles distant. Depth, 545 fathoms; bottom temperature, $38.7^{\circ}$ F.; bottom, brown mud and small stones. August 31, 1906.

Three medium-sized specimens.

Station No. 4980. - $34^{\circ} 09^{\prime} 00^{\prime \prime}$ north latitude, $137^{\circ} 55^{\prime} 00^{\prime \prime}$ east longitude. Depth, 507 fathoms; bottom temperature, $39^{\circ} \mathrm{F}$; bottom, brown mud, fine sand, and foraminifera. September 1, 1906.

Twenty-five medium-sized specimens.

Station No. 50r9.--34 $15^{\prime} 00^{\prime \prime}$ north latitude, $138^{\circ} 00^{\prime} 00^{\prime \prime}$ east longitude, Omai Saki Light bearing north $29^{\circ}$ east, 24 miles distant. Depth, 475 fathoms; bottom temperature, $39.1^{\circ} \mathrm{F}$; ; bottom, pebbles. October $19,1906$.

Two medium-sized specimens, 
Station No. 5082.-Two medium-sized specimens.

Station No. 5083. - Fifteen large specimens.

Eudiocrinus japonicus was found at depths of from 103 to 712 fathoms (mean 388 fathoms) with bottom temperatures ranging from $37.5^{\circ}$ to $56.0^{\circ} \mathrm{F}$, the mean being $43.5^{\circ} \mathrm{F}$. The largest specimens (arm $125 \mathrm{~mm}$., longest cirri $54 \mathrm{~mm}$.) are from station No. 4958, where E. varians was not found; but examples from station No. 5083 are nearly as large (arm $100 \mathrm{~mm}$., longest cirri $42 \mathrm{~mm}$.), and were associated with large individuals of the other species.

The two species were found associated at the following stations:

\begin{tabular}{|c|c|c|}
\hline $\begin{array}{c}\text { Station } \\
\text { number. }\end{array}$ & Depth. & $\begin{array}{c}\text { Bottom } \\
\text { tempera- } \\
\text { ture. }\end{array}$ \\
\cline { 1 - 1 } & & \\
4916 & Fathoms. & $\circ$ F \\
4919 & 361 & 42.7 \\
4975 & 740 & 41.8 \\
5082 & 612 & 37.5 \\
5083 & 662 & 37.7 \\
& 624 & 38.1 \\
\hline
\end{tabular}

E. varians only was found at--

\begin{tabular}{|c|c|c|}
\hline $\begin{array}{c}\text { Station } \\
\text { number. }\end{array}$ & Depth. & $\begin{array}{c}\text { Bottom } \\
\text { tempera- } \\
\text { ture. }\end{array}$ \\
\hline & & Fathoms. \\
4906 & $369-406$ & 43.4 \\
4911 & 391 & 41.9 \\
4912 & 391 & 41.9 \\
4915 & 427 & 41.9 \\
4920 & 440 & 41.8 \\
\hline
\end{tabular}

E. japonicus only was found at-

\begin{tabular}{|c|c|c|}
\hline $\begin{array}{c}\text { Station } \\
\text { number. }\end{array}$ & Depth. & $\begin{array}{c}\text { Bottom } \\
\text { tempera- } \\
\text { ture. }\end{array}$ \\
\hline & & Fathoms. \\
\cline { 2 - 3 } & & $\circ$. \\
4900 & 207 & 52.9 \\
4903 & $139-107$ & 52.9 \\
4934 & $152-103$ & 56.0 \\
4958 & 405 & 40.1 \\
4976 & 545 & 38.7 \\
4980 & 507 & 39.0 \\
5079 & 475 & 39.1 \\
\hline
\end{tabular}

The type of E. varians was obtained in $16^{\circ} 42^{\prime}$ north latitude, $119^{\circ} 22^{\prime}$ east longitude, in 1,050 fathoms, and that of E. japonicus in $34^{\circ} \tau^{\prime}$ north latitude, $138^{\circ} 0^{\prime}$ east longitude, in 565 fathoms, the temperature in the case of the former being $37^{\circ}$ and in the case of the latter $38.1^{\circ}$; while the natural inference would be that $E$. varians was an abyssal form inhabiting very cold water and $E$. japonicus a comparatively shallow-water form, the data here given suggests that in reality both 
have about the same habitat so far as temperature and depth are concerned, although it is worthy of note that at the stations with the least depth and highest temperatures E. japonicus alone was found. Another interesting fact is that at the stations where both species occurred together the examples of each were of practically the same size; where $E$. varians was large and robust $E$. japonicus was also large and robust, and, conversely, where E. varians was small $E$. japonicus was also small, thus suggesting that the same factors influenced the growth of each in the same degree.

Eudiocrinus japonicus can be distinguished at a glance from $E$. varians by its more robust and massive appearance. In color the two species are practically the same.

EUDIOCRINUS TUBERCULATUS Clark, new species.

In general similar to $E$. japonicus, but even more robust, with the junctions of the first eight or ten brachials strongly tubercular. The tubercle between the first two is in the median line; those on the following joints lie alternately on either side of the arm.

The greatest difference between this species and E. japonicus is in the character of the cirri; in E. tuberculatus they are but $18 \mathrm{~mm}$. in length consisting of about 17 joints, although the specimens are rather larger than any of my E. japonicus, in the largest of which the cirri reach $54 \mathrm{~mm}$. in length.

Station No. 3661.-Ofi Uki Shima, Gulf of Tokyo, 169 fathoms; bottom temperature, $48^{\circ} \mathrm{F}$; ; bottom, mud and pebbles. October 13, 1896.

Type.-Cat. No. 22604 U.S.N.M. from this station.

Three specimens.

The following is a list of the known recent species of Eudiocrinus:

$$
\text { EUDIOCRINUS P. H. Carpenter. }
$$

1882. Eudiocrinus P. H. Carpenter, Jour. Linn. Soc. (Zool.), XVI, p. 493 (first mentioned p. 488); new name for Ophiocrinus Semper, preoccupied.

Type.-Ophiocrinus indivisus Semper.

EUDIOCRINUS ATLANTICUS Perrier.

1883. Eudiocrinus atlanticus Perrier, Comptes Rendus, XCVI, p. 725.

Type-locality.-Gulf of Gascony, 896 meters. French steamship Travailleur.

\section{EUDIOCRINUS GRANULATUS Bel1.}

1894. Eudiocrinus granulatus Bell, Proc. Zool. Soc., 1894, p. 397, pl. XXIII (first mentioned p. 396).

Type-locality.-Macclesfield Bank, west of Luzon, Philippine Islands; 34-40 fathoms. H. M. S. Egeria. 


\section{EUDIOCRINUS INDIVISUS (Semper).}

1868. Ophioerinus indivisus SEmper, Arehiv für Naturgesch., Jahrg. 34, Bd. 1, p. 68 .

Type-locality.-Pandanon, near Bohol, Philippine Islands: 30 fathoms. Prof. C. Semper.

\section{EUDIOCRINUS JAPONICUS P. H. Carpenter.}

1882. Eudiocrinus japonicus P. H. Carpenter, Jour. Linn. Soc. (Zool.), XVI, p. 495; detailed description on p. 499.

Type-locality. $-34^{\mathrm{c}} 7^{\prime}$ north latitude, $138^{\circ} 0^{\prime}$ east longitude off the south coast of Nipon; 565 fathoms. H. M. S. Challenger.

\section{EUDIOCRINUS SEMPERI P. H. Carpenter.}

1882. Eudiocrinus sempen P. H. Carpenter, Jour. Linn. Soc. (Zool.), XVI, p. 495; detailed description p. 497.

Type-locality. $-34^{\circ} 8^{\prime}$ south latitude, $152^{\circ} 0^{\prime}$ east longitude, near Sydney, New South Wales; 950 fathoms (figured specimen). H. M. S. Challenger.

EUDIOCRINUS TUBERCULATUS A. H. Clark.

Type-locality.-Off Uki Shima, Gulf of Tokyo: 169 fathoms. U. S. S. Albatross.

\section{EUDIOCRINUS VARIANS P. H. Carpenter.}

1882. Eudiocrimus varians P. H. Carpenter, Jour. Linn. Soc. (Zool.) XVI, p. 495; detailed description p. 496; first mentioned p. 494.

Type-locality. $-16^{\circ} 42^{\prime}$ north latitude, $119^{\circ} 22^{\prime}$ east longitude, off the west coast of Luzon, Philippine Islands, 1,050 fathoms. H. M. S. Challenger. 


\section{$2 \mathrm{BHL}$ Biodiversity Heritage Library}

Clark, Austin Hobart. 1907. "On a collection of crinoids of the genus Eudiocrinus from Japan, with description of a new species." Proceedings of the United States National Museum 32(1551), 569-574.

https://doi.org/10.5479/si.00963801.32-1551.569.

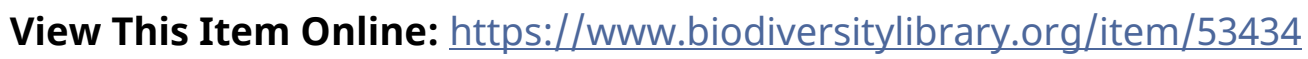

DOI: https://doi.org/10.5479/si.00963801.32-1551.569

Permalink: https://www.biodiversitylibrary.org/partpdf/51897.

\section{Holding Institution}

Smithsonian Libraries

\section{Sponsored by}

Smithsonian

\section{Copyright \& Reuse}

Copyright Status: Public domain. The BHL considers that this work is no longer under copyright protection.

This document was created from content at the Biodiversity Heritage Library, the world's largest open access digital library for biodiversity literature and archives. Visit BHL at https://www.biodiversitylibrary.org. 